\title{
Shallowly Discuss on How to Improve the Quality of Talents Training in Local College-Taking Jilin Province as Example
}

\author{
Aichen Liu \\ Jilin Agricultural University Jilin Changchun \\ 9558805@qq.com
}

Keywords: Local colleges and universities; Talent training; Quality

\begin{abstract}
Because the local colleges and universities are not allowed to be positioned, the investment is not enough and the degree of social acceptance of graduates is low, the quality of talent training is worrying. This article took Jilin Province as an example, the popularization of higher education as the background, to improve the quality of local colleges and universities personnel training as the core, firstly, analyzed the local college talent cultivation problems, then analyzes the causes of the problem, and finally proposed the establishment of professional oriented curriculum mode, construction of "dual qualification" teaching mode, took the depth of school enterprise cooperation mode of several measures.

With the rapid development of China's higher education, the quality of personnel training as a direct embodiment of the level of education has aroused widespread attention in Colleges and universities. What points out in national medium and long term educational reform and development planning outline $(2010$ - 2020) is: "Improving quality is the core task of the development of higher education, and is the basic requirement of building a powerful country in higher education." Therefore, the local colleges and universities in Jilin province should also respond to the national call, and constantly improve the quality of personnel training.
\end{abstract}

\section{On the Quality Factors of Talent Cultivation in Local Colleges and Universities in Jilin Province}

In the process of promoting the reform of higher education, the quality of training depends on many factors, source problem is the source of the quality of personnel training; the orientation of talent cultivation is the leading direction of talent cultivation; how the students' employment is the final interpretation of the quality of personnel training, so these factors are mutual influence and interaction, to improve the quality of personnel training, we should pay more attention to these problems in the process of training.

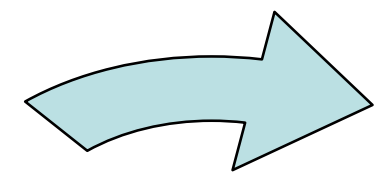

Lack

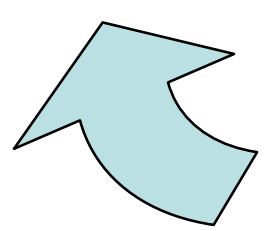

Employment

Location

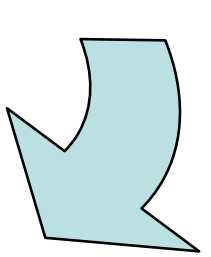

Figure 1.

Lack of Students. Affected by geographical location, strength and reputation, and other factors, 
the local colleges and universities in Jilin province are in a disadvantaged position, and they lack the characteristics of running school, and the school's resources are relatively small. Cause social satisfaction is not high, eventually in the admissions process often appear the problem of lack of students and other issues, the student enrollment rate is not high. At the same time, colleges and universities mainly occupied absolute advantage in terms of enrollment, not only enjoy the national policy tilt, and has abundant resources, higher visibility, and there is a clear distinction between the key and non-key universities in the psychological, so that this kind of colleges and universities has a lot of students. In this context, the university to obtain more student market, also added some independent college or school and the school admission scores tend to be lower than the key universities, in order to attract a lot of local university newspaper was prepared to take the candidates.

Location Deviation. For institutions of higher learning, the goal of talent training is focused on "what kind of person", which plays an important role. With the popularization of higher education, undergraduate diploma has been more common, which makes people change the social expectation of higher education radically, among them, students and parents are no longer concerned about where to go, but more concerned about where to go"; Employers no longer focus on what students learn from the school, but instead focus on what they "can do", highlighting the "employability" of college graduates ". Under this background, local colleges and universities must change the mode of talent training in time and improve the quality of personnel training. However, under the guidance of social value orientation, local colleges and universities are becoming more and more utilitarian, the distribution of the government is in accordance with the assessment and ranking of universities for resources, which makes local colleges and universities blindly pursue the "high level", and strive to focus on the unified teaching process, while ignoring the characteristics and the established goal of talent training. Position deviation of the goal of cultivating talents in local colleges in Jilin province lead to difficult to achieve "running characteristics at different levels and in different areas, striving for the top" teaching target.

Employment Difficulties. The ultimate goal of local colleges and universities is to cultivate talents, and the employment situation also reflects the quality of university personnel training. On the current stage of the overall employment situation, the employment of this phenomenon is very common. Society provides jobs to a certain extent, affect the employment situation, and more important is that local colleges and universities are difficult to train a lot of people are difficult to make use of the unit. In recent years, the employment rate of local colleges and universities in Jilin province and the two employment rate is relatively low, the problem of employment is significant.

\section{Analysis on the Reasons of the Problems of Local Colleges and Universities in Jilin Province}

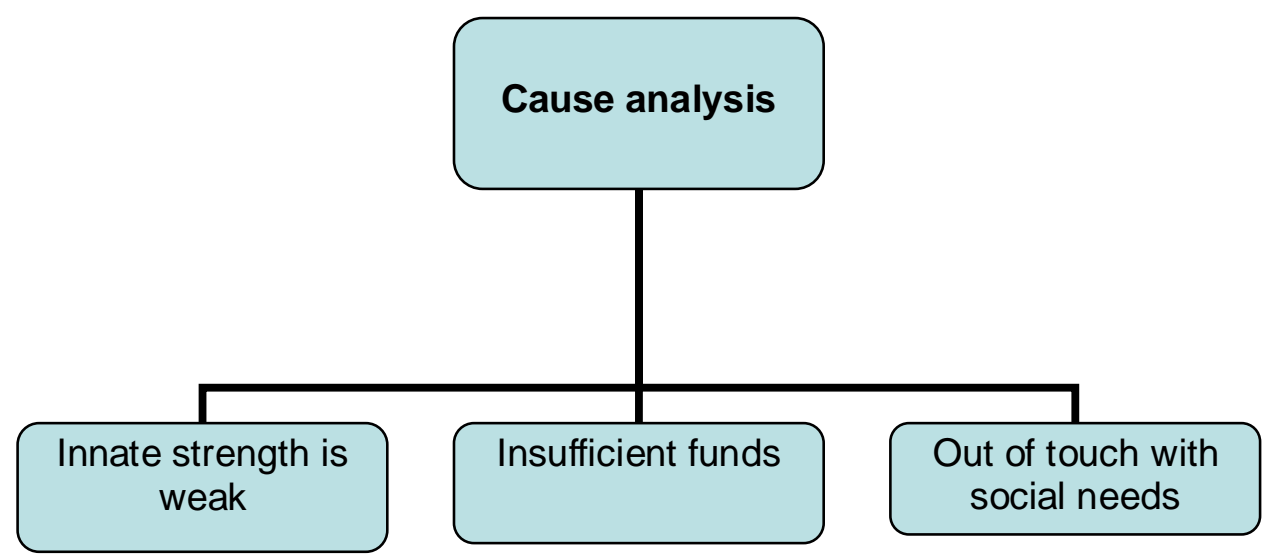

Figure 2.

Innate Strength Is Weak. The local colleges and universities in Jilin province are weak, with relatively poor the conditions of running schools, and the low popularity. Firstly, it is limited by 
local colleges and universities' own financial resources; secondly teachers, local colleges and universities are difficult to retain the high education, high professional title, and the introduction of high-quality teachers, is even more difficult; Thirdly discipline categories are not comprehensive enough, and lack of adequate research results, leading to the lack of awareness of the school; Fourthly affected by the popularization of higher education, the growing competition in the market, local colleges and universities for students is less attractive to drop from the "value", the overall quality of students is not high, which must inevitably affect the quality of talent training.

Insufficient Funds. Many local colleges and universities are faced with the problem of raising funds, local colleges and universities in Jilin province is no exception. This is because the long-term investment in education funding is not, seriously restricting the quality of personnel training to improve. Especially in the background of the rapid development of higher education, local colleges and universities are more nervous.

Out of Touch with Social. Local colleges and universities in Jilin province is difficult to stand in the "employability" perspective to look at the issue of talent training. They often do not take into account the "import and export" of personnel training, it will not be in accordance with the requirements of the employment market and economic development of the situation to be targeted, the purpose is to cultivate talents. In this case, some local colleges and universities have formed their own characteristics of professional or professional, due to the status quo, do not understand the innovation and can't follow the frontier education, the curriculum setting and teaching mode lag, make its professional advantages gradually lost, and weaken the social influence, the training of talents is difficult to adapt to social demand. Some local colleges set up a new profession, because of quick success, but in the absence of reasonable talent training scheme, experimental conditions and teaching conditions are not fully equipped with the case, then begin teaching, resulting in disjointed between personnel training and social needs, resulting in students' difficult employment.

\section{Measures for Improving the Quality of Talents Training in Local Colleges and Universities in Jilin Province}

Establish a Professional Oriented Curriculum Model. For local colleges and universities in Jilin Province, there are some differences between the training objectives and key universities, the direction for applied talents, therefore, in terms of curriculum design, from work requirements, focus on the cultivation of students' ability, enhance the quality of education. In the process of talent training, the knowledge of the subject has played a fundamental role, therefore, the local colleges and universities in Jilin Province in the process of personnel training, should strengthen the cultivation of professional construction and application ability, forming a "professional orientation and Application Oriented Curriculum Model in order to improve the quality of personnel training.

Construction of "Double Teacher" Teaching Model. Teachers, as the main body of University communication knowledge / training talents, play a vital role in improving the quality of personnel training. Local colleges and universities in Jilin Province in the process of improving the quality of personnel training, should strengthen the construction of teachers, they should be capable of high efficiency, good quality and innovation, but also should have a strong ability to apply; They should not only master the basic knowledge of the discipline theory, but also have a wealth of practical experience; They should not only have a strong teaching ability, but also have excellent observation ability, analysis ability and operation ability.

At the same time, in the process of teaching, teachers should also timely introduction of new technology at home and abroad, to make classroom teaching as far as possible to the daily production and life, to encourage students to learn the knowledge and practical work to achieve seamless. At the same time, the local colleges and universities in Jilin province should also provide a good environment for the teaching and research of teachers, build a scientific and rational incentive system, through the "keep" and "treatment" and "feelings" to ensure the stability of teachers. In addition, the introduction of local colleges and universities should also pay attention to the talent to change the past "not sticking to formalities, education theory" and "the title of", to pay attention to the quality of teachers themselves, such as knowledge structure, knowledge update, 
aesthetic taste and personality charm, through the strengthening of teachers to improve the quality of personnel training.

Take the Mode of Cooperation between Colleges and Enterprises. To improve the employment rate and solve the problem of employment of local colleges in Jilin Province, taking the mode of school enterprise cooperation is the only way. At present, many local colleges and universities in Jilin province have developed this idea, and have carried on the practice, however, often did not reach the depth of cooperation. Affected by various factors, many enterprises lack appropriate personnel, and lack local colleges and universities and the initiative, enthusiasm. Under such background, it is imperative to carry out the cooperation between schools and enterprises, and the specific measures are as follows: Firstly, in the construction of laboratories, to ensure that the laboratory equipment and related equipment used by the company basically the same; Secondly, in the process of technical practice, to ensure that students can experience the real work environment to form the ability to solve problems independently; Thirdly, take the dual system of training mode, so that colleges and universities to complete the teaching and learning.

In addition, the local government should also implement the "quality competition, hierarchical input" fiscal policy, promote the rational allocation of local higher education resources, increase capital investment, to provide funding for local talent cultivation in Colleges and universities.

\section{References}

[1] C.L.Wei, L.Liu and W.W.Wang. Construction and Operation of the Quality Assurance System of Talent Training Based on Collaborative Governance in Local Colleges and Universities [J]. Chinese University Teaching, 2012, 12:66-68. (In Chinese)

[2] Y Cui. Discussion on the Application Oriented Talents Training Model of Tourism Management Major under the Background of Transformation of Local Colleges and Universities -- Taking Jilin Province as an example [J]. Vocational and Technical Education, 2015, 29:16-19. (In Chinese)

[3] F.Yang and Y.Pan. Colleges and Universities in Jilin Province Based on the Local Economy "Double [J]." Talent Cultivation Mode of Contemporary Educational Practice and Teaching Research, 2016, 03:134-135. (In Chinese)

[4] S.S.Feng, W.W.Zheng and J.G. Chen. Research on Training Quality of Applied Talents in Local Colleges and Universities [J]. Heilongjiang Higher Education Research, 2015, 04:132-134. (In Chinese)

[5] X.Han. Cooperation to Improve the Quality of Training Talents in Local Colleges [J].Chinese University Science and Technology, 2015,11:52-53. (In Chinese) 